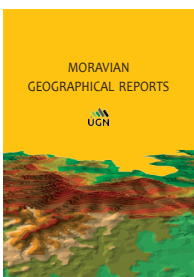

The Czech Academy of Sciences, Institute of Geonics

journal homepage: http:/www.geonika.cz/mgr.html

doi: https://doi.org/10.2478/mgr-2020-0003

\title{
Changes in urban transport behaviours and spatial mobility resulting from the introduction of statutory Sunday retail restrictions: A case study of Lodz, Poland
}

\author{
Marta BOROWSKA-STEFAŃSKA a ${ }^{\text {a }}$ Michał KOWALSKI ${ }^{\text {a }}$, Szymon WIŚNIEWSKI ${ }^{\text {* }}$
}

\begin{abstract}
The impact of statutory Sunday retail restrictions on the transport behaviours of people living in the Polish post-socialist city of Lodz is investigated in this article. One carrier of information on journeys undertaken in the city is data from induction loops - a part of the city's Intelligent Transportation System (ITS). The second source of data is a two-stage questionnaire survey (concerning trading and non-trading Sundays) of the city's inhabitants, aimed at defining any changes in their transport behaviours with reference to the introduction of retail restrictions. The research was conducted to assess the way in which the new statutory restrictions affect transport behaviour discharged after the political transformation. The results of the research conducted on the transport behaviours of Lodz residents indicate that the majority of their transport behaviours clearly depend on whether a given Sunday is a trading or non-trading day. The traffic load of the urban road network (perceived as the manifestation of residents' spatial mobility) is characterised by a distinct changeability due to the legislative restrictions related to Sunday trading. There is both a time (daily and hourly) differentiation of traffic flows and a spatial changeability of the load in the urban space, when a comparative analysis is conducted of the results of observations made in the weeks preceding trading and non-trading Sundays. The study also demonstrates that the time previously devoted to Sunday shopping is currently spent not only at home, but also allocated to new (and until now unperformed) activities that often require travelling.
\end{abstract}

Keywords: spatial mobility, transport behaviour, retail restrictions, Intelligent Transportation Systems, Lodz, Poland

Article history: Received 28 June 2019, Accepted 26 February 2020, Published 31 March 2020

\section{Introduction}

In geographical and sociological research, mobility is a concept that encompasses both the multi-scale movement of people, goods, capital and information, and the local phenomena related to daily trips and travelling in the public space (Hannam et al., 2006). In this article, we focus on spatial mobility, which Kaufmann (2005) divides into four types: (I) short-term, within a certain distance of home - daily mobility; (II) short-term, outside a certain distance of home - travel (including tourism); (III) longterm, within a certain distance of home - residential change; (IV) long-term, outside a certain distance of homemigration (Borowska-Stefańska and Wiśniewski, 2019; Komornicki, 2011).

In line with this classification, our studies focus mainly on short-term mobility within a certain distance of home. Mobility results from trips taken to fulfil certain needs
(Hannam et al., 2006). Numerous studies on transport behaviours indicate the strong position of shopping in the hierarchy of such needs (Carp, 1988; Vilhelmson, 1999; Kraft, 2014). The introduction of legislation with respect to shopping days - such as the Polish Act on retail restrictions on Sundays and public holidays, as well as some other specified days (Item 305 published in the Official Journal of Laws of the Republic of Poland ("Dziennik Ustaw")) in March 2018, has become a barrier restricting the possibilities of fulfilling this particular need.

Existing studies - conducted by various researchers, including economists (Szromnik, 2017), sociologists (Szul, 2015), and geographers (Rochmińska, 2016) demonstrate that shopping and spending leisure time in trading facilities is an important and popular element of people's Sunday activities. In Poland, the traditional, Catholic image of the weekend (and Sunday in particular)

\footnotetext{
${ }^{a}$ Institute of the Built Environment and Spatial Policy, Faculty of Geographical Sciences, University of Lodz, Lodz, Poland (*corresponding author: S. Wiśniewski, e-mail: szymon.wisniewski@geo.uni.lodz.pl)
} 
has undergone dramatic changes during the period of social, political and economic transformation (Č́byová et al., 2014; Szromnik and Wolanin-Jarosz, 2018). Changes in the job market have brought about alterations to working conditions, including varied forms and rules of employment, which are translated into substantial changes to the ways and standards of social life of both individuals and whole families, including, in particular, the amount and ways of spending free time (Rochmińska, 2011). Therefore, it appears to be quite legitimate to scrutinise the impact that the statutory restrictions have exerted on people's transport behaviours in Poland.

The research reported here focuses on the transport behaviours of residents in a large city, their mobility (expressed by traffic volumes on the road and street network), and the effects of legal regulations related to Sunday trading. The juxtaposition of these three elements allows us to analyse the impact of the legislation - implemented to protect employees' rights to free Sundays by releasing those in the retail trade from their obligation to work on Sundays, and to create equal competition opportunities for the smallest retail shops (which reported the greatest losses when big-box stores appeared on the Polish market) - on social behaviours, whose transformation legislators did not take into account. Such behaviours include those related to transport - understood as a statistically-described set of transport decisions made by a specified population in a given territorial unit, and identified on the basis of a questionnaire survey and traffic load measurements.

The main purpose of this article is to determine the impact of the statutory Sunday retail restrictions on the transport behaviours of people living in a large post-socialist city, and it will be accomplished through the completion of the following detailed objectives:

- The analysis of transport behaviours of residents on trading and non-trading Sundays;

- Identification of the reasons behind any possible changes in transport behaviours related to the Sunday retail restrictions and the extent of their relation with (independence from) the ban;

- Indication of features of temporal and spatial differentiation regarding residents' mobility, the expression of which is the load of the urban road network on non-trading and trading Sundays; and

- Scrutiny of spatial, daily and hourly variability of vehicle numbers within the road and street network reported during weeks with and without trading Sundays, and presented with reference to spatial management.

This paper, which presents mobility during working days and weekends, contains data on weekdays preceding trading and non-trading Sundays, and weekends with or without trading Sundays. The final section of the article focuses on a comparison of transport behaviours among Lodz residents in the said periods, including an attempt to determine by means of data from induction loops - what impact the implementation of the statutory retail restrictions has had on changes in transport behaviours.

The second part of the article provides a review of the research into and studies on the links between spatial mobility and trade, with a particular focus on post-socialist cities. The third part presents the source materials used in the paper and the research methods applied in the analytic procedures, while the fourth section contains the empirical analysis of changes in transport behaviours among Lodz citizens that have resulted from the introduction of the statutory retail restrictions, which is followed by a scrutiny of the results, a summary of such, as well as conclusions and recommendations for further studies. Due to the fact that the retail restrictions were implemented relatively recently (2018), the resultant changes in spatial mobility constitute a new and significant research issue, which should contribute to the development of scientific research into such issues. In Poland, this research issue is an absolute novelty, since the statutory restrictions were only introduced in 2018, and their effects in various areas will most likely be the subject of further research.

\section{Theoretical background}

The issue of regulation concerning shop opening hours has been regularly discussed in many European countries over the last two decades. Such discussions have resulted in a softening of the legal restrictions in, for instance, Great Britain, Holland and Germany, but regulations with regard to Sunday trading still vary considerably in different European countries (Dijkgraaf and Gradus, 2006, 2007; Genakos and Danchev, 2015; Kay and Morris, 1987). Currently, numerous countries are holding heated debates on the opening hours of retail shops and other facilities. Some participants advocate for unrestricted competition and greater customer freedom, while others believe that the rights of retail trade employees to free Sundays for relaxation and leisure time must be respected (Temperini and Gregori, 2015). Naturally, Sunday retail restrictions also bring effects and consequences apart from mobility changes. These include their impact on the labour market (Paul, 2015), and the distribution of the lost turnover from non-trading Sundays (Choi and Jeong, 2016). The conclusions to be drawn there are partially related to spatiality, and thus, they may be used to theorise on customers' spatial behaviours.

In general, deregulation of restrictions imposed on shops with regard to business hours translates into an increase in expenses and a drop in the number of small shops (Nooteboom, 1983). The spatial model developed by Morrison and Newman (1983) - which premises that the price of a given good is the resultant of the price itself and additional costs as a result of the time spent by the consumer in purchasing the item - allows us to assume that the sales volume will grow in large stores and diminish in small shops if the opening hours are prolonged, and the effect will be reversed in the case of more substantial legal regulation in the matter. As regards Sunday trading, some researchers believe that competitive pressures may induce excessive opening on Sundays, when high costs would be incurred (naturally followed by price increases; Kay and Morris, 1987). The empirical evidence collected in the United Kingdom, however, shows that this does not occur in practice, and that the deregulation of opening hours of retail facilities leads to a decrease in costs and prices (Gradus, 1996). Although the imposition of Sunday trading restrictions results in a slight drop of net sales (if we take into account the growth observed on other days of the week), and leads to people shopping on alternative days and, partially, also in different places (e.g. small shops: Choi and Jeong, 2016), in their study on changing business hours, Bell et al. (1997) indicate that such restrictions encouraged consumers to shop where stores were clustered, thus reducing their time-based costs.

In Poland, attempts to introduce statutory Sunday retail restrictions have been made on a number of occasions over recent years, for example in 1999 and 2014. The issue 
resurfaced in 2016 with the submission of a bill initiated by citizens over Sunday retail restrictions (supported by Solidarity, the largest trade union in the country). Consequently, an act on retail restrictions on Sundays and public holidays, as well as certain other days, was introduced in Poland in March, 2018: Dz.U. 2018 item 305, as amended with regard to changes to the provisions of the Entrepreneurs' Law Act and other acts concerning business activity, Dz.U. 2018 item 650). In accordance, the trading ban will be introduced gradually. Shops have been open on two Sundays per month since March 2018 and will be open on only one Sunday from 2019, and from 2020 the ban will include all Sundays apart from seven (three Sundays before holidays, as well as the last Sundays in January, April, June and August: Stelina, 2018). Under the Act, only those retail facilities in which the owner or the owner's household members (the closest family) are directly in charge of handling retail activities, may operate on all Sundays and public holidays. As a result, transport needs with regard to travelling to shopping facilities encountered a major barrier.

The above changes should be perceived through the prism of the characteristics of consumer behaviour - which are quite distinctive in post-socialist countries. Retail in Poland developed on the basis of the pre-requisites typical of free-market countries until the outbreak of World War II. In turn, during the socialist period retail - initially being the domain of mercantilism and co-operatives, continuing pre-war traditions (even in the 1940s, the share of such initiatives was $89 \%$ of the whole country's retail: Kaliński, 1968) - was in time subject to quite rapid nationalization under the concept of "battle for trade" promoted by the domestic socialist authorities of that time (the Polish Workers' Party) (Åslund, 1985). As a result, as early as in the 1950s the share of the private sector in retail turnover slumped to a mere $3.2 \%$.

The last decade of socialism, however, did see a very slow transformation of retail in Poland. The share of collectivised retail in the total retail turnover shrank from $98 \%$ in 1981 to $95 \%$ in 1989 , although this hardly changed its monopolist position in the economy (Kaliński, 2015). In the years of the centrally-planned economy in Poland, Chudzyńska (1985) notices that "theoretical models of service localisation assume that a service point of a given function should be located in each settlement unit of the population that is larger or equal to the break-even point for this function" (p. 14). She adds that service points are generally located in places of the highest market accessibility, in which there is a tendency to concentrate service points and consequently form service centres. In practice, however, in socialist times, especially in its last decades, most shops in Poland offering food, chemical and household goods were more and more visibly undersupplied, etc. (Lesiakowski, 2012). In the last decade of socialism, retail trading was primarily based on small shops and simplistic forms of retail outlets (e.g. market stands, stalls and booths), and, less frequently, on department stores.

In the period of political transformation (late 1980s and early 1990s), the Polish economy saw, on the one hand, rapid privatisation due to a number of conditions and crises, and, on the other, the demise of many ill-managed state-owned enterprises. Even though numerous small retail units began to appear on the market (Taylor, 2000; Dzieciuchowicz, 2013), the potential for domestic capital to support the development of large retail facilities remained low on a nation-wide scale. The introduction of a free-market economy and the opening of the domestic market to foreign investors, resulted in a rapid expansion of retail chains in Poland. This transformation put an end to the problems connected with the availability of basic products, which since that time have often been offered in new, modern premises such as supermarkets, hypermarkets and shopping centres (Kaczmarek, 2011; Kowalski, 2018).

The spatial behaviours of Poles was considerably affected by the aforementioned deficiencies, and the low level of organisation of retail clashed with a highly developed form of retail. Consequently, due to the high concentration of retail, these facilities (shopping centres) began to play an increasingly important role in shaping the network of all kinds of relations and connections, integrating many social and economic phenomena which took place in the postsocialistic city (Dinic-Brankovic et al., 2018; Heffner and Twardzik, 2015a) as well as in western countries (Bennison and Davies, 1980; Hopkins, 1991; Lowe, 2005). Over time, and with growing competition, these facilities extended their offer to include services other than retail, which consequently increased their impact as they no longer depended only on the scale of retail concentration but also on certain non-retail attractors (Cudny, 2016). As a result, these facilities have become contemporary temples of consumption (Ritzer, 2005; Xavier, 2018), particularly for post-socialist societies (Rembowska, 2008). Such phenomena bring about, for instance, considerable traffic-generating potential from these places, which, in consequence, translates into the efficiency of the city's transport layout in the areas in which they function (Romanowska and Jamroz, 2015).

Apart from changes in spatial and purchasing behaviours following the transformation of retail in post-socialist countries, particularly in Poland, the socialist system did not reflect "hidden" features of Poles, such as their liking for ownership or independence in everyday life. The political transformations awoke behaviours previously quashed, which were additionally reinforced by accounts of lifestyles abroad shared by the numerous Polish diaspora living mainly in the United States (including transport behaviours: Komornicki, 2003). All this leads to Poles changing their transport choices as they get richer - more and more often choosing a car to fulfil their transport needs (the expression of which is a very rapid increase in car ownership rate) at the expense of public transport or alternative means of personal transport. Additionally, some distinctive factors shaping the car ownership rate in Poland include: the prestige and social position resulting from owning a car (Lijewski, 1998); the relative ease of owning a car when compared to possessing a residential property (Menes, 2001); privatisation and decentralisation of the economy, as well as high indirect labour costs (Komornicki, 2011). Taking into account the historical background of transformations in retail trade and the development of motorisation in post-socialist countries, one must bear in mind that Sunday trading restrictions may have different repercussions there when compared to countries that have enjoyed a free market economy for decades.

\section{Data and methods}

The first source of information on journeys undertaken within the city is data from induction loops that are part of the Intelligent Transportation Systems (ITS) functioning within the city boundaries of Lodz. The second source is 
a questionnaire survey conducted in two stages (concerning trading and non-trading Sunday) with the city's inhabitants, aimed at defining changes in their transport behaviour with reference to the introduction of retail restrictions. The results of the questionnaire survey were analysed to determine the extent of their relation with (or independence from) the Sunday shopping ban (using a chi-squared test). The strength of the correlations that occurred depend on the legislative change and were analysed by means of Cramér's V. Another analysis focused on the spatial, daily and hourly variability of vehicle numbers within the road and street network, reported during weeks with and without trading Sundays. This involved calculating changes in traffic volume and the percentage of such changes, traffic distribution during weeks with and without retail restrictions, changes in traffic distribution and median for differences in traffic volume, the standard deviation for differences in traffic distribution, and the rate of variability of differences in traffic volume. The results presented here originate from the two aforementioned sources. Since the two types of data differ substantially (surveys have a declarative nature, while data from induction loops are relatively objective), the third part of the article has been divided into three sections: Subsection 3.1 characterises the survey questionnaire and the respondents; Subsection 3.2 contains a description of data from the induction loops; and Subsection 3.3 refers to the research area, Lodz, a large city in central Poland.

It must be emphasised that the two types of data used in this study - namely the data collected from surveys and those from ITS sensors - are meant to complement, rather than substitute for one another. After all, the questionnaire survey focuses on a specific cohort of respondents whose mobility within the urban area (a manifestation of transport behaviour) was, in all probability, also recorded by the local ITS (just like trips taken by all other residents). It is, however, beyond our possibilities to select and isolate this group (respondents) within the database, since the ITS data from induction loops contains evidence of all motor vehicles (including buses and construction vehicles) that were detected within the city's transport system during the researched period. Induction loops (a measurement component of the ITS) are installed within the road surface and react to the electromagnetic spectrum emitted by objects that travel above them. Unfortunately, the ITS in Lodz does not allow us to classify vehicles. There are ITS systems which do offer this functionality, but unfortunately the solution applied in Lodz is not one of them. Even if it did offer the possibility to recognise public transport vehicles, their timetable is unaffected by trading restrictions, so it would be necessary to measure the number of passengers on board. From our research perspective, however, this is an inconvenience that excludes the possibility of drawing unambiguous conclusions on factors determining the volume and spatial distribution of traffic flows. Nevertheless, if we look at the ITS data through the prism of the survey, we may expand our reasoning with potential co-occurrence of certain regularities which stem from the respondents' answers and objective measurements conducted via the ITS sensors.

\subsection{Questionnaire survey and profile of respondents}

For the purposes of the study, a two-stage questionnaire survey was conducted. In both of these stages the same dwellings were visited. The first stage was carried out during a week following a non-trading Sunday (November 19-23), and the respondents were asked to refer exclusively to that Sunday (i.e. November 18). The second stage was conducted during a week following a Sunday with no trading restrictions (November 26-30), and the questions again focused only on that previous Sunday (i.e. November 25). Apart from respondent socio-demographic characteristics, the questionnaire contained open-ended and 'semi-open' questions that inquired about the number of trips taken; the reasons why: "if there were no trips", and the time spent at home. Next, the respondent was asked to determine their motivation behind each trip at a specified time, the means of transport they used, including the number of changes of vehicle/transport mode, travel time, the hour of departure and arrival, and the starting point and destination, including any errands and destinations 'en route'. During the second stage, the questionnaire was expanded, with questions referring to the impact of the statutory Sunday trading ban on their shopping habits and time management. Additionally, there was also a question - aimed at respondents who usually did their shopping on Sunday - about how they allocated the free time that would normally be spent in the shops.

The unit of observation in the research was single- or multi-member households, as well as household members of age of 16 or more living in the selected dwellings. The number of household members neither determined nor excluded households from the survey. In the case of multimember households, the selected respondent was a person currently at home, and if there were more members present, we selected the dweller whose date of birth (day and month) was closest to the date when the survey was conducted. The questionnaire focused on the respondent's traits and behaviours, with some questions also regarding the whole household (e.g. number of household members, average income). In some cases, assistance was provided by the head of the family or a decision-making adult. The applied age limit (16 years of age or older) stems from practices of traffic research in Poland, and is meant to take into account respondents who make relatively 'independent' mobility decisions (with a particular focus on shopping decisions), as these people were expected to fill in the journey log. It was assumed that the transport behaviours of younger users of the urban transport system depended substantially on decisions made by their parents/legal guardians. These youths are persons who have completed the primary level of education (the only obligatory requirement in Poland).

The research was carried out with a selected sample of 465 dwellings from the city of Lodz and had the character of voluntary anonymous research. The sample selection took place in two stages. The first stage involved choosing a 5\% sample of primary sampling units, which are census areas or groups of census areas (comprising at least 15 dwellings). The secondary sampling units were dwellings. Three dwellings were selected for the main sample, and three for the reserve sample from each of the previously chosen census areas. 155 census areas (from 3,107, with number of dwellings not smaller than 15), and then 465 dwellings were selected for the research. The selection of surveyed areas (i.e. meeting the requirement of a sufficient number of homes) involved the city as a whole (the entire area was divided into the smallest unit of spatial classification, i.e. a census tract). The selection of homes in individual neighbourhoods (census tracts) was also conducted at random. 
The sample was not representative, however, which stemmed mainly from financial limitations. Another obstacle to implement a representative sample was the time allocated for the questionnaire surveys, which had to be conducted promptly after the selected Sundays so that the respondents would provide reliable answers. Being aware of the drawbacks of this approach, the authors followed good research practices in the matter and refrained from applying extensive generalisations, for example to other cities. The implications, then, are that we are dealing with a largely exploratory study.

Consent to take part in the research was more often given by women than men - with women representing nearly 60 per cent of the survey's participants (the feminisation ratio being over 119 women to 100 men), hence women are slightly overrepresented in research output data. Two groups of respondents are clearly prevalent with reference to education: those with a secondary education (almost 45 per cent) and a higher education (nearly 34 per cent). The average age of respondents was 42 . The majority of respondents work in professional occupations. The largest group is made up of respondents who work outside their home (79.5 per cent). The most popular sectors among respondents include administration and other services (about 20 per cent each). The majority of persons in employment do not work on Sundays (slightly over 76 per cent). In turn, only a small number of individuals declared that they had to work every Sunday ( 0.5 per cent; see Tab. 1 for details).

Respondents who took part in the survey represented 2-person (slightly over 31 per cent) and 3-person (almost 28 per cent) households in the majority of cases. With regard to the professional situation, relatively, 2 persons working professionally (nearly 61 per cent) make up the largest number of households. The largest number of respondents declared a net income in the region of 350-460 EUR (with an exchange rate of 4.3 to PLN) per person in the household (slightly over 34 per cent), followed by a group with an income between 230-350 EUR net per person (almost 23 per cent), and then 460-580 EUR (slightly over 20 per cent). The average net income per person in a household is 447 EUR (Tab. 1).

\subsection{Data from the ITS (induction loops)}

The carrier of information on journeys undertaken within the city is the data from induction loops that are part of the city's Intelligent Transportation System (ITS) in Lodz (Kowalski and Wiśniewski, 2017a; Borowska-Stefańska et al. 2019). Data from a complete two-week period were obtained from the Lodz ITS (the week before a trading Sunday, and the week before a non-trading Sunday), which preceded the Sundays included in the questionnaire survey so as to ensure that any conclusions refer to the same timing.

Relying on data from induction loops imposes certain preliminary assumptions. This is information with an extremely high time accuracy, obtained from a large set of measurement points. Yet it fails to provide any qualitative data; hence the analysis was extended to include the abovementioned questionnaire survey. Apart from the number of vehicles which passed through the given detector in the analysed time interval, the researcher does not have access to any other direct information. It is only through "superimposing" the network of induction loops on the city's functional and spatial structure that it is possible to make general conclusions about the distribution of potential travel sources and destinations. It is also necessary to assume that no other factors conditioning volumes of traffic on the city's road and street network were subject to any changes in the analysed periods. In brief, it is assumed that changes in the time and spatial structure of vehicle traffic result solely from retail restrictions.

Characterising the general distribution of the system's measurement elements (induction loops), it should be pointed out that they are concentrated mostly in the city centre, and if they do go beyond it, they tend to accompany key transport arteries in the meridional and latitudinal layout. Such a distribution greatly affects any subsequent conclusion-making process on the basis of research results conducted with the given data. There are also many issues the solution for which cannot be based on certain interpolations or extrapolations of the data obtained from ITS measurement tools. Analysing the data from the ITS, one should bear in mind that the spatial mobility of the population recorded in them - i.e. their transport behaviours - is not really "natural", as the ITS alone affects the registered flows by, for instance, favouring tram transport or setting the phase length of traffic lights. This is obviously a natural part of the city's transport system, yet one should take into account that the picture emerging from the analysis of data obtained from the ITS is not only the result of decisions taken by traffic participants.

The functioning of induction loops may be encumbered with all kinds of errors and breakdowns, the result of which may be, for example, flawed results of vehicle count measurements (Li et al., 2014). This is why, after collection from the ITS, data control is necessary as the system alone does not detect such kinds of errors. This basic information on the spatial mobility of the population enables the undertaking of numerous problem analyses. An example of this could be the influence of retail restrictions on the city's transport system. It is possible, however, to present the volume of movement made by vehicles using the monitored sections of the urban road network in the region, where the given city's spatial structure elements occur (Kowalski and Wiśniewski, 2017b): in this case, retail facilities. Data obtained from the city system allows one to pinpoint the 'real' traffic generating potential. Data adopted in this research project by no means replaces information on travel motivations, sources and destinations, collected directly from traffic participants. They only present the load on the network, being, in a way, an expression of the choices made by road users at any given time. Consequently, research of this type is general - or holistic - as it refers to all car movements without indicating any individual dimensions of mobility.

These factors help to explain why it is impossible to depict the traffic generating potential of shopping centres on the scale of the whole city, without the possibility of isolating this part of traffic in traffic flows - connected with transit (including intra-city transit). In this context, the major value of the current research project resides in combining the data on the volume of movements (data from the ITS) in the regions where the given development and (retail) function occurs (data from the Head Office of Geodesy and Cartography), with the results of the conducted questionnaire survey.

\subsection{Area under study}

As the third most populated urban agglomeration in Poland, Lodz has a demographic structure which places it among both the most feminised and fastest-ageing cities - 


\begin{tabular}{|c|c|c|c|c|c|}
\hline \multicolumn{2}{|l|}{ Characteristics $(N=465)$} & \multirow{3}{*}{$\begin{array}{c}\text { Share [\%] } \\
59.8 \\
40.2\end{array}$} & \multicolumn{2}{|l|}{ Characteristics $(N=465)$} & \multirow{2}{*}{$\begin{array}{c}\text { Share }[\%] \\
77.6\end{array}$} \\
\hline \multirow[t]{2}{*}{ Gender } & Female & & \multirow{2}{*}{$\begin{array}{l}\text { Possession of a driving licence } \\
\text { by respondents }\end{array}$} & Yes & \\
\hline & Male & & & No & 22.4 \\
\hline \multirow[t]{7}{*}{ Education } & Primary & 0.9 & \multirow{7}{*}{$\begin{array}{l}\text { Number of bicycles in the } \\
\text { household }\end{array}$} & 0 & 29.5 \\
\hline & Junior high school & 1.1 & & 1 & 22.4 \\
\hline & Vocational & 15.5 & & 2 & 30.1 \\
\hline & Secondary & 44.7 & & 3 & 11.6 \\
\hline & Post-secondary & 4.1 & & 4 & 5.4 \\
\hline & Higher & 33.7 & & 5 & 0.8 \\
\hline & & & & $6+$ & 0.2 \\
\hline \multirow[t]{6}{*}{ Age } & $17-25$ & 12.0 & \multirow[t]{6}{*}{ Number of cars in the household } & 0 & 21.3 \\
\hline & $26-35$ & 22.4 & & 1 & 54.0 \\
\hline & $36-45$ & 26.9 & & 2 & 23.2 \\
\hline & $46-55$ & 17.4 & & 3 & 1.5 \\
\hline & $56-65$ & 15.1 & & & \\
\hline & $66-75$ & 6.2 & & & \\
\hline \multirow{11}{*}{$\begin{array}{l}\text { Net income per person } \\
\text { in the household per month }\end{array}$} & $<230$ EUR & 10.5 & \multirow[t]{11}{*}{ Employment } & Pupil & 1.3 \\
\hline & 230-350 EUR & 22.6 & & Student & 3.9 \\
\hline & $350-460$ EUR & 34.3 & & orking/working casual & 2.4 \\
\hline & 460-580 EUR & 20.4 & & Work outside home & 79.5 \\
\hline & 580-700 EUR & 6.9 & & Work at home & 1.9 \\
\hline & 700-820 EUR & 1.9 & & Pensioner/retired & 8.4 \\
\hline & 820-940 EUR & 1.3 & & Unemployed & 2.2 \\
\hline & $940-1,060$ EUR & 0 & & Other & 0.4 \\
\hline & 1,060-1,180 EUR & 0.4 & & & \\
\hline & > $1180 \mathrm{EUR}$ & 0.2 & & & \\
\hline & refusal to answer & 1.5 & & & \\
\hline \multirow{11}{*}{$\begin{array}{l}\text { Household size } \\
\text { (number of persons) }\end{array}$} & 1 & 13.1 & \multirow{11}{*}{$\begin{array}{l}\text { Business sector working } \\
\text { respondents }(\mathrm{N}=390)\end{array}$} & Other services & 20.6 \\
\hline & 2 & 31.4 & & Administration & 20.3 \\
\hline & 3 & 27.7 & & Industry & 14.6 \\
\hline & 4 & 20.0 & & Architecture & 11.0 \\
\hline & 5 & 5.6 & & Trade & 9.0 \\
\hline & 6 or more & 2.2 & & Science & 7.9 \\
\hline & & & & Transport & 7.4 \\
\hline & & & & Healthcare & 4.6 \\
\hline & & & & Culture & 2.8 \\
\hline & & & & Other & 1.5 \\
\hline & & & & Agriculture & 0.3 \\
\hline \multirow{6}{*}{$\begin{array}{l}\text { Number of people working } \\
\text { in the household }\end{array}$} & 0 & 7.5 & \multirow[t]{6}{*}{ Working on Sundays $(\mathrm{N}=390)$} & Work every Sunday & 0.5 \\
\hline & 1 & 19.4 & & Work some Sundays & 23.1 \\
\hline & 2 & 60.6 & & No work on Sundays & 76.4 \\
\hline & 3 & 9.5 & & & \\
\hline & 4 & 2.8 & & & \\
\hline & 5 & 0.2 & & & \\
\hline
\end{tabular}

Tab. 1: Basic characteristics of the respondents Source: authors' survey 
with a low rate of natural increase (RNI) and a negative net migration rate - resulting in the fact that it is dominated by small households. The majority of its residents used to work for state-run industries (mostly in the textile industry), which led to them being economically weak. Although almost 25 years have passed since the political transformations, the city has only slowly gained economic momentum, with an average income of its citizens still remaining lower than in other large Polish cities. Nevertheless, the improving economic situation in reflected in the retail market (see Tab. 2).

The structure of the city's urban area consists of two distinct zones: outer and inner one, the boundaries of which are delineated by the railway line that rings the city (Lamprecht and Wojnarowska, 2013). The sociospatial structure of Śródmieście (Downtown) is dominated by the lower class, with minor pockets of middle class (Marcińczak, 2007). Traditionally, Midtown plays a trading role, which is occasionally supplemented by out-of-town shopping centres and numerous supermarkets located in the residential areas. The most significant elements of the outer zone are rapidly developing housing estates built during the $1970 \mathrm{~s}$ and $1980 \mathrm{~s}$, vast and expansive multi-use industrial zones, modern housing developments (Milewska-Osiecka, 2010) and industrial and warehousing zones (see Fig. 1)

The street layout in Śródmieście takes the form of a $19^{\text {th }}$ century grid and becomes gradually less regular the farther you depart from the city centre. Roads in Śródmieście are of low efficiency and capacity, which leads to most of the district's network being greatly overloaded.
The main transport axes of the city (grid patterns) are streets and avenues of national and regional roads running longitudinally and latitudinally. Besides the layout of streets in Śródmieście, another factor that determines the district's accessibility is the network of express and motorways which form an unclosed ring road. The spatial structure of the areas located in the immediate vicinity of ITS devices installed on Lodz roads is dominated by transport infrastructure and built-up zones (mostly housing estates, and service and trading facilities: see Fig. 1). Even though mobility in Lodz is not an extensively explored phenomenon and its characteristics can only be found in secondary analyses (Tab. 2), it can be stated that the majority of shopping trips in the city, just like in any other large urban area in Poland, are taken by car (Bartosiewicz and Pielesiak, 2019).

\section{Results and discussion}

\subsection{Mobility conditioning connected with retail}

The car ownership rate in Lodz is 55 passenger cars per 100 persons. This indicator includes both vehicles belonging to households and companies. This indicator is predominantly achieved by those surveyed households in which the net income per inhabitant exceeds 460 EUR (values calculated at the EUR-PLN exchange rate of 4.3) hence considerably exceeding the average household income per person in the region, which is 362 EUR. The highest car ownership rate is observed in those households with a high income (see Tab. 3) and clearly increases with a rise in net income per inhabitant.

\begin{tabular}{|c|c|c|c|c|c|c|c|c|c|c|c|c|c|}
\hline \multicolumn{4}{|c|}{ Demography and employment } & \multicolumn{2}{|c|}{ Females } & \multicolumn{2}{|c|}{ Males } & \multicolumn{2}{|c|}{ Total } & & & & \\
\hline \multicolumn{4}{|l|}{ Number of residents (2017) } & \multicolumn{2}{|c|}{375,786} & \multicolumn{2}{|c|}{314,636} & \multicolumn{6}{|c|}{690,422} \\
\hline \multicolumn{4}{|l|}{ Number of employees (2017) } & \multicolumn{2}{|c|}{130,868} & \multicolumn{2}{|c|}{116,702} & \multicolumn{6}{|c|}{247,570} \\
\hline \multicolumn{4}{|c|}{ Number of employees in retail industry $(2017)^{* *}$} & \multicolumn{2}{|c|}{29,460} & \multicolumn{2}{|c|}{33,927} & \multicolumn{2}{|c|}{63,387} & & & & \\
\hline \multirow{2}{*}{\multicolumn{2}{|c|}{ Number of households (2011) }} & & & \multicolumn{2}{|c|}{1 person } & \multicolumn{2}{|c|}{2 persons } & \multicolumn{2}{|c|}{3 persons } & \multicolumn{2}{|c|}{4 persons } & \multicolumn{2}{|c|}{$5+$ persons } \\
\hline & & \multicolumn{2}{|c|}{324,892} & \multicolumn{2}{|c|}{$33.6 \%$} & \multicolumn{2}{|c|}{$31.3 \%$} & \multicolumn{2}{|c|}{$20.1 \%$} & \multicolumn{2}{|c|}{$10.8 \%$} & \multicolumn{2}{|c|}{$4.1 \%$} \\
\hline \multicolumn{14}{|l|}{ Retail } \\
\hline \multirow{2}{*}{\multicolumn{2}{|c|}{ Number of retail facilities (2017) }} & & & \multicolumn{2}{|c|}{ Hypermarkets } & \multicolumn{2}{|c|}{ Supermarkets } & \multicolumn{2}{|c|}{$\begin{array}{l}\text { Department } \\
\text { stores }\end{array}$} & \multicolumn{2}{|c|}{$\begin{array}{l}\text { Seasonal mar- } \\
\text { ketplaces }\end{array}$} & \multicolumn{2}{|c|}{$\begin{array}{c}\text { Permanent } \\
\text { marketplaces }\end{array}$} \\
\hline & & & & & 0 & & & & & & & & \\
\hline Value of retail sales (2017) & & & & Pol & & & & & & Lodz Vo & odeshi & & \\
\hline & & Tot & mill. $\mathrm{E}$ & $\mathrm{JR}]$ & Per & capita []. & UR] & Tot & [mill. & UR] & Per & apita [1 & UR] \\
\hline & & & 3,426.4 & & & $4,904.1$ & & & $9,185.0$ & & & , 703.7 & \\
\hline Changes of retail sales & year & & 2007 & 2008 & 2009 & 2010 & 2011 & 2012 & 2013 & 2014 & 2015 & 2016 & 2017 \\
\hline Lodz Volvodeship & in tot & & 3.8 & 2.7 & 1.4 & 5.4 & 12.8 & 0.3 & 0.2 & -0.7 & 4.0 & 7.8 & 12.1 \\
\hline & per $\mathrm{c}$ & {$[\%]$} & 4.2 & 3.0 & 1.7 & 5.4 & 13.2 & 0.7 & 0.7 & -0.3 & 4.5 & 8.3 & 12.5 \\
\hline
\end{tabular}

Mobility

Average annual number of trips per resident (2015)

Total

450

By car

26

By car

16.5
Shopping trips

40

By public transport 28

On foot

16

By public transport

10.3

Tab. 2: Selected demographic and economic data related to retail and mobility in Lodz (Notes: * YoY - the year over year; **retail with repair of motor vehicles; transportation and storage; accommodation and catering; information and communication). Source: authors' elaboration based on the Central Statistical Office (GUS) data 


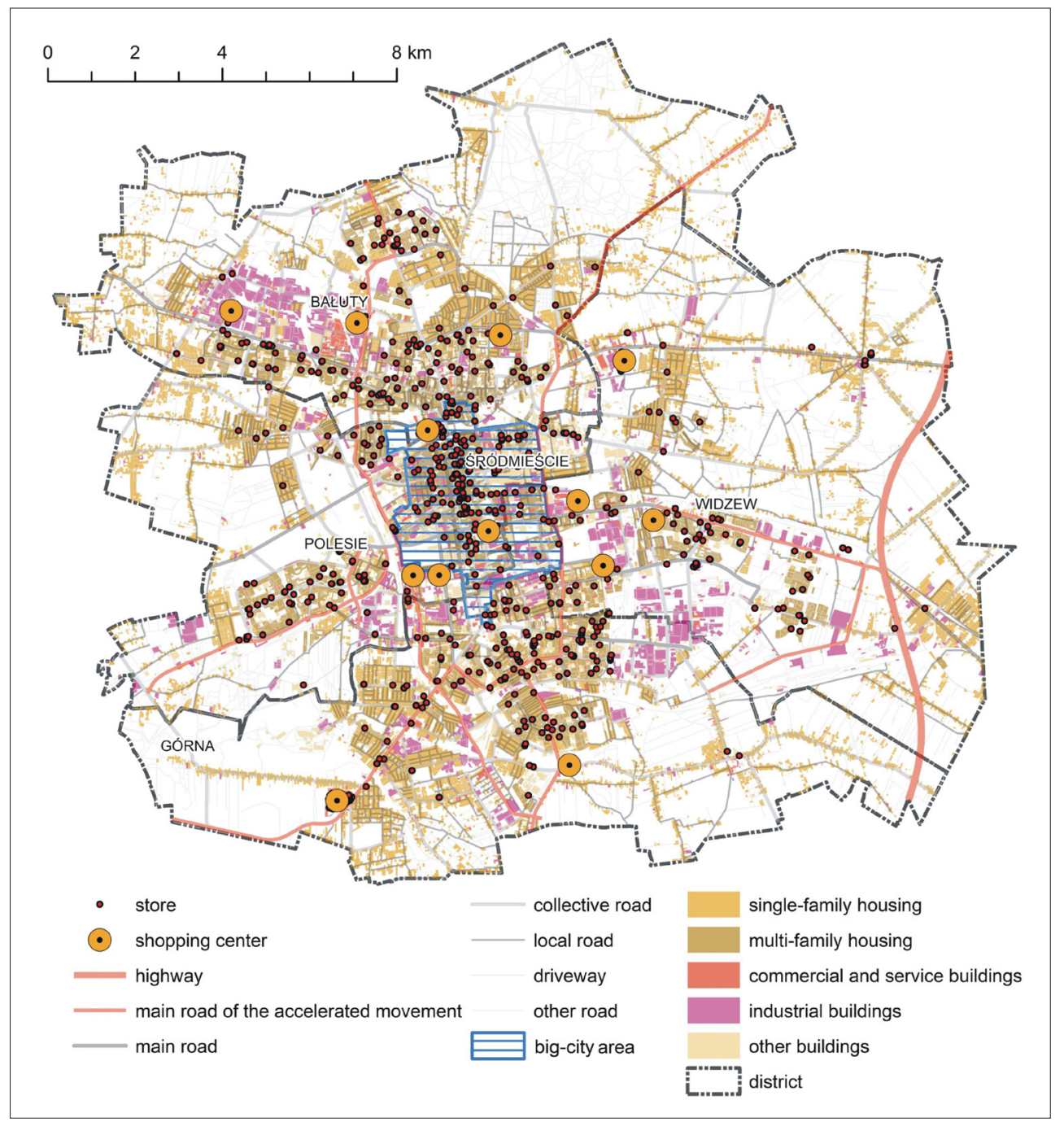

Fig. 1: Distribution of stores and shopping centres against the background of housing development and the road network in Lodz. Source: authors' survey

\begin{tabular}{ccccc}
\hline Net income of a household per inhabitant & $\begin{array}{c}\text { Cars per } \\
\text { 100 household }\end{array}$ & $\begin{array}{c}\text { Cars per } \\
\text { 100 persons }\end{array}$ & $\begin{array}{c}\text { Cars per } \\
\text { 100 working persons }\end{array}$ \\
\hline PLN & EUR & No. & No. & No. \\
\hline$\leq 1,000$ & $\leq 233$ & 92 & 27 & 64 \\
$1,001-2,000$ & $234-465$ & 99 & 33 & 54 \\
$2,001-3,000$ & $466-698$ & 23 & 51 & 63 \\
$>3,000$ & $>699$ & 104 & 54 & 63 \\
\hline
\end{tabular}

Tab. 3: Number of cars in households. Source: authors' survey

The majority of respondents declare that they adjusted their shopping needs to Saturday due to the Sunday trading ban - or they claim that they did not do any shopping on Sunday in any case, which is why they do not feel restricted by the ban. A large group of respondents altered their Sunday shopping to one of the weekdays (Fig. 2). Most people pointed to other kinds of impact of the ban on their purchasing behaviours, indicating that they go to bars and restaurants as it is impossible to do grocery shopping on a non-trading Sunday.

Table 4 shows the detailed distribution of declarations concerning the impact of the Sunday trading ban on ways of doing shopping. Research participants who declared that the ban on Sunday trading made them organise their shopping at a different time, were later asked to indicate how they used the time on Sunday which they would have spent on shopping, if there was no trading ban. The results show that more than half of them spent this time on activities which require travelling (Fig. 3 ).

There is a lot of research concerning shopping facilities in post-socialist cities as places to spend leisure time (Majchrzak, 2007; Novák and Sykora, 2007; Humphrey and Skvirskaja, 2009). Rochmińska (2011) analysed customers at the shopping centres in Lodz, demonstrating that, irrespective of gender, their presence in such facilities is a way of spending free time for 22.6 per cent of the customers, mostly young people. At the same time, she showed that whether they spent their free time in retail 


\begin{tabular}{|c|c|c|c|c|c|}
\hline \multirow[t]{2}{*}{ Impact of the trading ban } & & \multicolumn{4}{|c|}{$\begin{array}{c}\text { Groups of households according to net income } \\
\text { per inhabitant* [in \%] }\end{array}$} \\
\hline & & $\leq 233$ EUR & 234-465 EUR & 466-698 EUR & > 699 EUR \\
\hline \multirow{3}{*}{$\begin{array}{l}\text { Nothing has changed - did not do any } \\
\text { shopping on Sunday anyway }\end{array}$} & in total & 33 & 36 & 20 & 46 \\
\hline & men & 38 & 49 & 27 & 55 \\
\hline & women & 28 & 27 & 17 & 38 \\
\hline \multirow{3}{*}{$\begin{array}{l}\text { Nothing has changed - still does shopping } \\
\text { on Sunday but in shops in which the trading } \\
\text { ban does not apply (small family-run shops) }\end{array}$} & in total & 6 & 9 & 6 & 4 \\
\hline & men & 8 & 9 & 4 & n.a. \\
\hline & women & 4 & 8 & 6 & 8 \\
\hline \multirow[t]{3}{*}{ Now does shopping on Saturday } & in total & 33 & 32 & 44 & 25 \\
\hline & men & 21 & 22 & 33 & 27 \\
\hline & women & 44 & 39 & 50 & 23 \\
\hline \multirow[t]{3}{*}{ Now does shopping in the week } & in total & 16 & 20 & 23 & 17 \\
\hline & men & 21 & 17 & 24 & 9 \\
\hline & women & 12 & 23 & 22 & 23 \\
\hline \multirow[t]{3}{*}{ Does not do any shopping at all } & in total & 12 & 3 & 5 & n.a. \\
\hline & men & 13 & 3 & 9 & n.a. \\
\hline & women & 12 & 3 & 2 & n.a. \\
\hline Other & in total & 0 & 0 & 2 & 8 \\
\hline
\end{tabular}

Tab. 4: The declared impact of the trading ban on shopping behaviour according to gender and income per person in the household

Source: authors' survey

Note: *In Poland, the average income per capita amounts to approx. $€ 370$ (Polish Central Statistical Office, 2017)

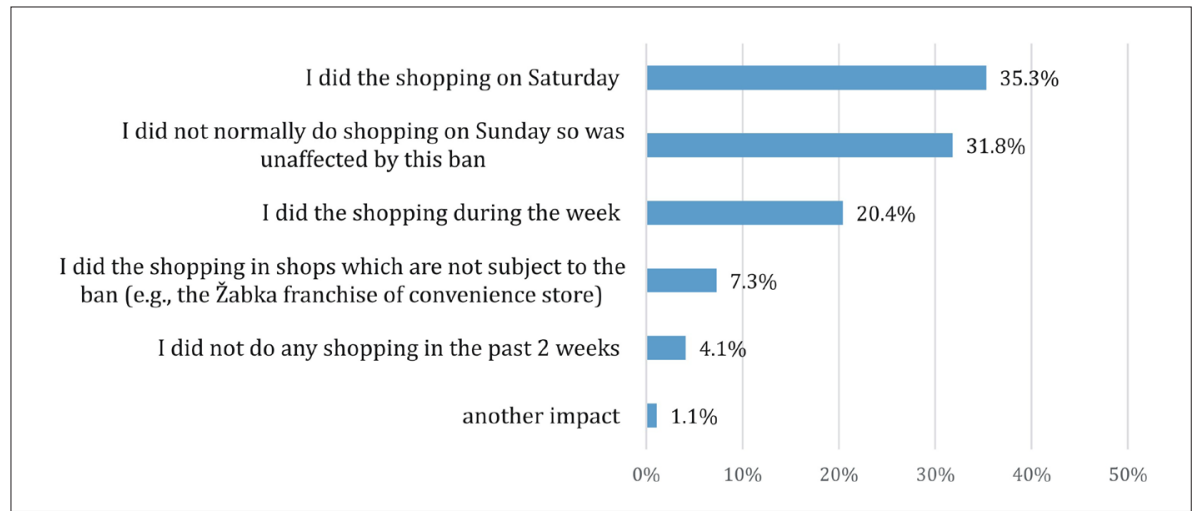

Fig. 2: Impact of Sunday retail restrictions on shopping habits

Source: authors' survey

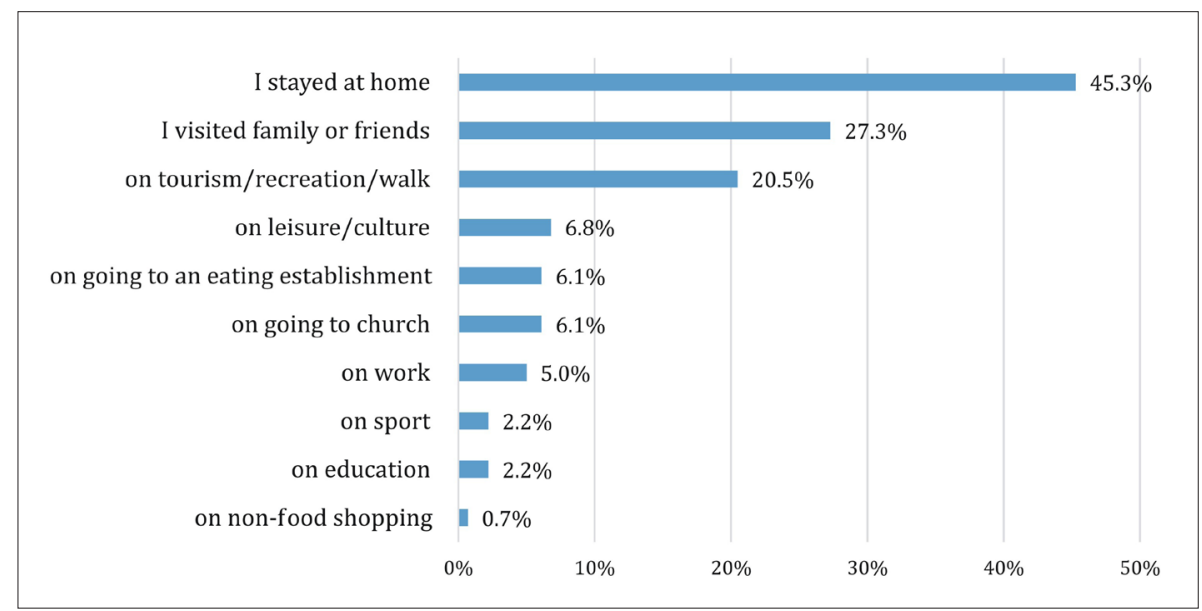

Fig. 3: The use of free time generated as a result of the Sunday trading ban Source: authors' survey 
facilities depended largely on their own assessment of their material status. As many as 33.2 per cent spent their time in this and not in any other fashion on Sundays. Our research shows that the majority of respondents (over 64 per cent) stated that they did not feel any impact of the ban on trading on the way they spent their free time at the weekend. Over 23.2 per cent of respondents see the positive impact of the introduction of the ban on Sunday trading, whereas $12 \%$ said the ban on Sunday shopping adversely affected the way they organising their leisure time. This is also confirmed by the calculated chi-square statistic - where the introduction of retail restrictions had an impact on motivations, numbers, modal division and duration of trips. It must be stated, however, that the influence is slight for each of these elements, with the highest association for trip duration (see Tab. 5).

The results concerning travel motivation point out that respondents tend to spend this day visiting their family and friends, regardless of whether the Sunday is subject to the ban on trading or not. Nevertheless, respondents see their family and friends more often on non-trading Sundays. In addition, respondents undertake activities connected with tourism and recreation (including walks), culture and leisure, eating out and engaging in sport with greater frequency on non-trading Sundays. On trading Sundays, the respondents did their shopping more often, which seems to be obvious. In this respect, the greatest changes in travel motivation concern shopping other than for food. This shows that the shops which can be open (run by the owner or the owner's family) offering these types of products on non-trading Sunday are not an attractive destination. This may be due to the fact that people are more willing to do shopping of this kind (e.g. in the category of fashion, electronics, white and brown goods, etc.) in places where there is a considerable concentration of facilities offering such products (e.g. in shopping centres), which under the new act are closed on Sundays.

Interestingly, the share of journeys to church is observed to be actually lower on non-trading Sundays. Generally speaking, Polish society stands out among many other societies which went through the period of socialism due to the fact that a vast majority of Poles declare themselves to be believers, predominantly Christians (87.58 per cent Catholics, 2.41 per cent atheists, 0.41 per cent Orthodox, 0.36 per cent Jehovah's Witnesses, 0.18 per cent Protestants, 7.1 per cent refused to make any declarations with regard to belonging to a religious organisation) (GUS). Consequently, the doctrines of these churches require the Sabbath day (or Sunday) to keep it holy. This is why the Catholic Church in Poland supported the act banning Sunday trading. It turns out, however, that inhabitants went to church more often on trading Sundays, possibly combining their shopping trips with going to church.

Changes in the duration time of the afore-mentioned activities on trading and non-trading Sundays are small and are within standard errors. The largest number of activities took from 30 minutes to 1 hour, activities requiring an hour to accomplish represented 20 per cent, whereas activities lasting less than half an hour represented slightly over 17 per cent. More than 55 per cent of respondents made one journey, 13 per cent 2 , and over 3 per cent 4 trips on a Sunday with the ban on trading. More than 27 per cent of respondents did not travel on a non-trading Sunday, pointing to their lack of need to go out as the main reason for this state of affairs (Fig. 4).

It transpires, however, that despite a relatively large number of people who made at least one journey during a non-trading Sunday, the overwhelming majority spent over 10 hours at home (slightly over 96 per cent). Two groups of about two per cent of respondents stayed at home less than 5 hours and from 5 to 10 hours each.

Even though habits related to means of transport do not change on trading and non-trading Sundays, their percentage does differ slightly. On trading Sundays, the respondents are more eager to walk and travel by car as passengers, and on non-trading Sundays, they use public transport more frequently (see Tab. 5).

The research results show that journeys undertaken on a trading Sunday are much longer than those on a Sunday with restricted trading. The average time of all trips on a trading Sunday is 37 minutes (30-minute trips dominate), where the average duration of the first or the only journey is 43 minutes, the second - 33 minutes, the third - 42 minutes, the fourth -30 minutes. In the case of non-trading Sundays the average time for the first or the only journey is 38 minutes, the second -27 minutes, the third - 19 minutes; the fourth - 14 minutes (see Tab. 5). Analysis of the type and place of activity for the inhabitants of individual districts clearly shows that their general

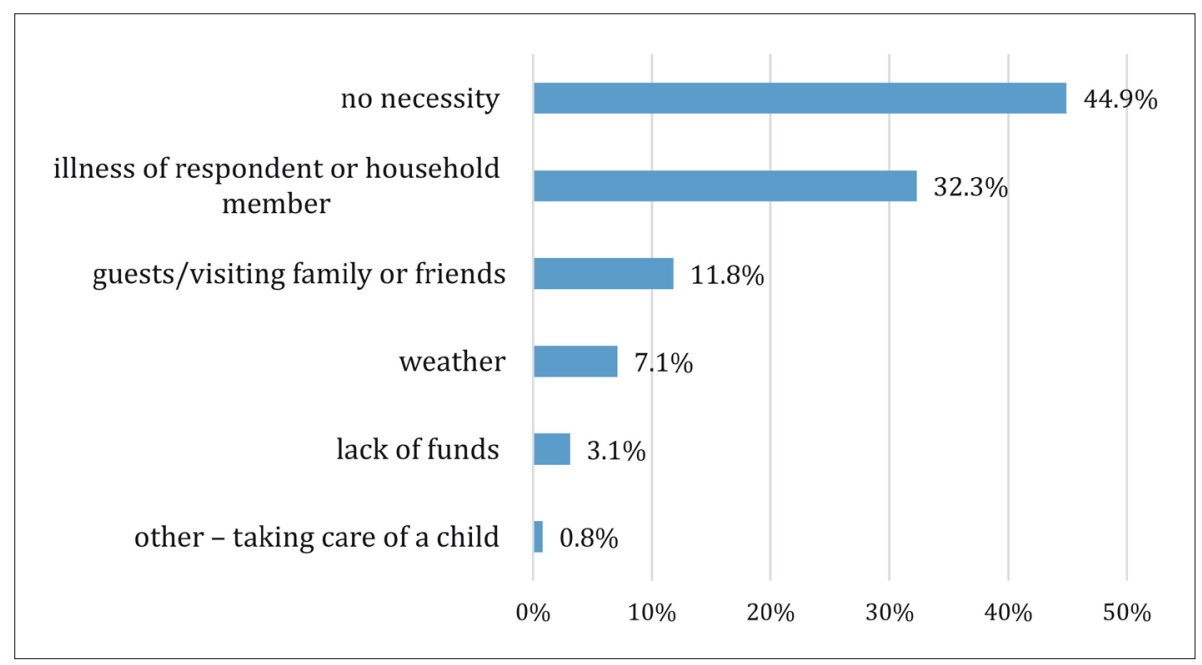

Fig. 4: Reasons for staying at home on non-trading Sunday Source: authors' survey 


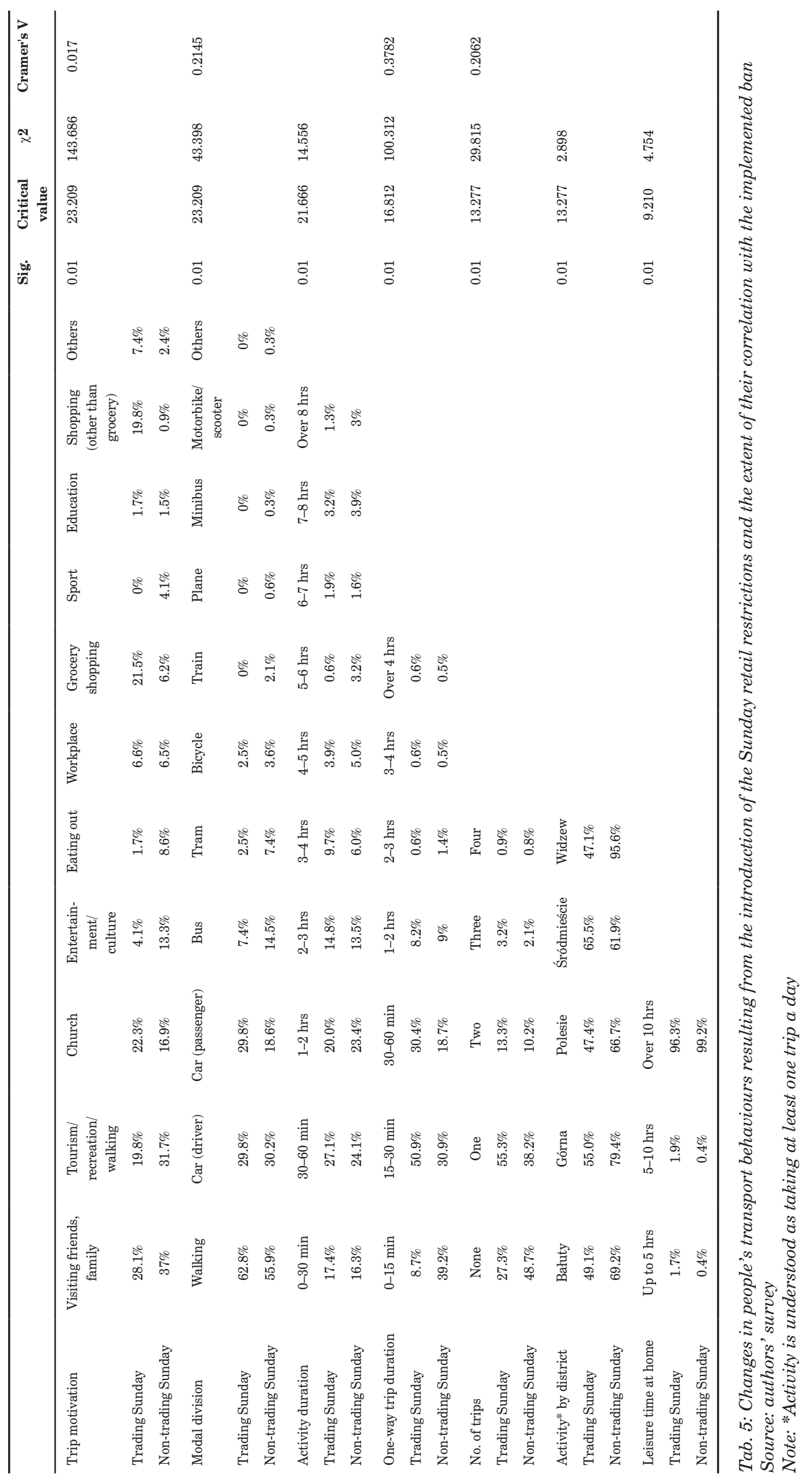


mobility is restricted to the immediate vicinity of their places of residence. The vast majority of respondents did not cross the boundary of their district in order to shop for food, engage in some recreational activity or fulfil spiritual needs. The largest mobility, i.e. travelling outside their district, was observed in the case of non-food shopping and visiting family and friends, in which case the percentage of journeys outside the city was clearly higher.

\subsection{ITS research}

The outcomes presented above were juxtaposed with empirical data from the ITS: as mentioned above, however, the information contained in both databases does not correspond directly one to the other: see Tab. 6). As a result, it seems that the heavier traffic observed on the Saturdays preceding the Sundays with the ban on trading, is confirmed by the questionnaire survey results (an increase of over 11 percent in traffic volume was observed on Saturdays preceding Sundays with the trading ban. In addition, it is interesting to observe the difference between just after 6 p.m. and 9 p.m. on Saturdays. It appears that the high value of the aforementioned difference reveals that some customers realised quite late that the access to retail would be restricted for the following 24 hours and made a last-minute decision to shop on Saturday evening. It should be noticed that the greatest role in this respect is represented by the ITS data obtained at the beginning of the year, which is the period when the act on the trading ban came into force. It is necessary, however, to confirm this conclusion in subsequent survey research (there was no question concerning the time of doing shopping on Saturday in the research presented here). When we assume other mobility-motivating factors to be permanent, it is worth noticing that Sunday retail restrictions had an impact on the distinctly noticeable increase in vehicle traffic during the working week. The said increase was not compensated for by a lower number of vehicles recorded by detectors on Sunday (Tab. 6).

The spatial distribution of changes in the load on the road network shows unambiguously that on Saturdays preceding non-trading Sundays traffic is heavier in the vast majority of measurement points (Fig. 6). The aforementioned increases are particularly visible both in the vicinity of shopping centres and along those roads acting as the main axes connecting them with housing areas (and at the same time, being part of the basic transport layout).

\begin{tabular}{lccccccc}
\hline & MON & TUE & WED & THU & FRI & SAT & SUN \\
\hline Traffic in a week without retail restrictions [veh.] & $7,084,840$ & $7,093,999$ & $7,235,917$ & $7,303,608$ & $7,543,059$ & $5,917,129$ & $5,026,990$ \\
Traffic in a week with retail restrictions [veh.] & $7,407,257$ & $7,505,784$ & $7,641,739$ & $7,731,889$ & $7,875,149$ & $6,590,186$ & $4,865,094$ \\
Change of traffic volume [vehicles] & 322,417 & 411,785 & 405,822 & 428,281 & 332,090 & 673,057 & $-161,896$ \\
Percentage of change of traffic volume [\%] & 4.55 & 5.80 & 5.61 & 5.86 & 4.40 & 11.37 & 3.22 \\
$\begin{array}{l}\text { Traffic distribution in a week without retail } \\
\text { restrictions [\%] }\end{array}$ & 15.01 & 15.03 & 15.33 & 15.47 & 15.98 & 12.53 & 10.65 \\
Traffic distribution in a week with retail & 14.93 & 15.13 & 15.40 & 15.58 & 15.87 & 13.28 & 9.81 \\
restrictions [\%] & & & & & & & \\
Change of traffic distribution [pp] & -0.08 & 0.10 & 0.07 & 0.11 & -0.11 & 0.75 & -0.84 \\
Percentage of change of traffic distribution [\%] & 0.53 & 0.66 & 0.48 & 0.72 & 0.67 & 5.96 & 7.92 \\
\hline
\end{tabular}

Tab. 6: Time and spatial differentiation of residents' mobility, the expression of which is the load of the urban road network during trading and non-trading Sundays

Source: authors' survey

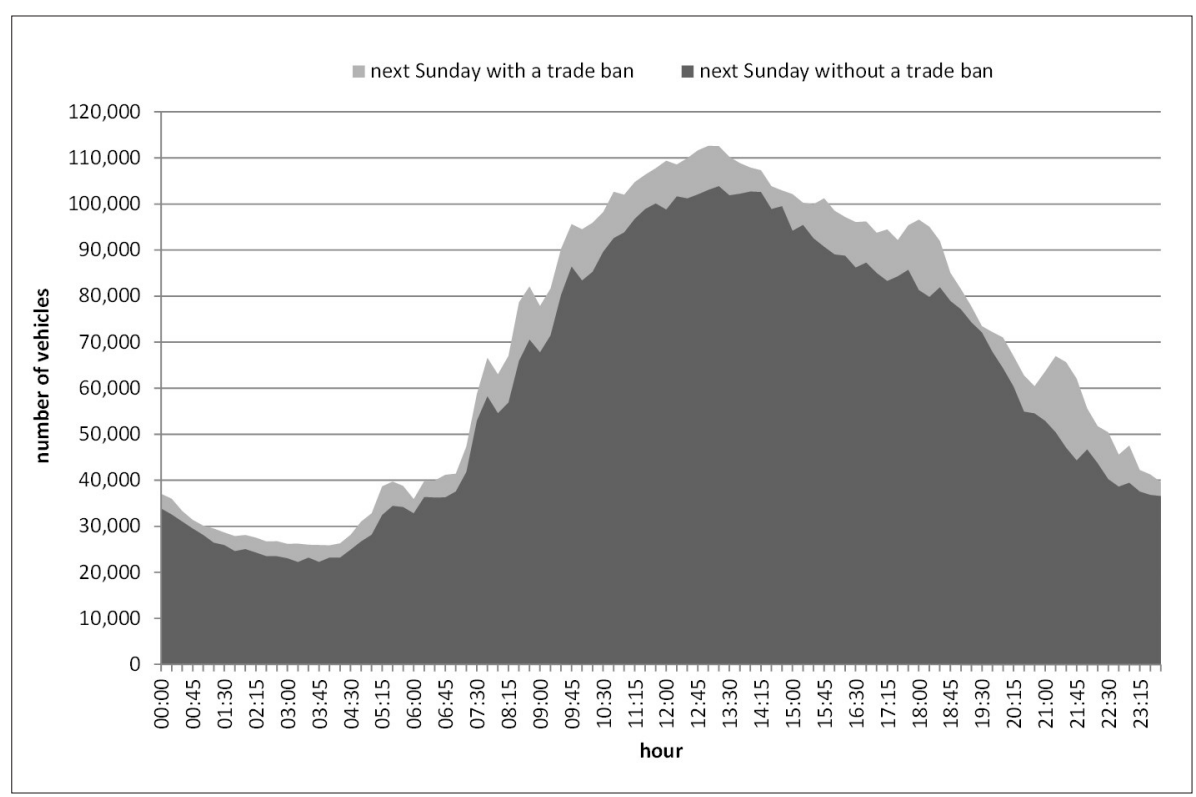

Fig. 5: The number of vehicles on Saturdays before Sundays with and without the ban on trading Source: authors' survey 


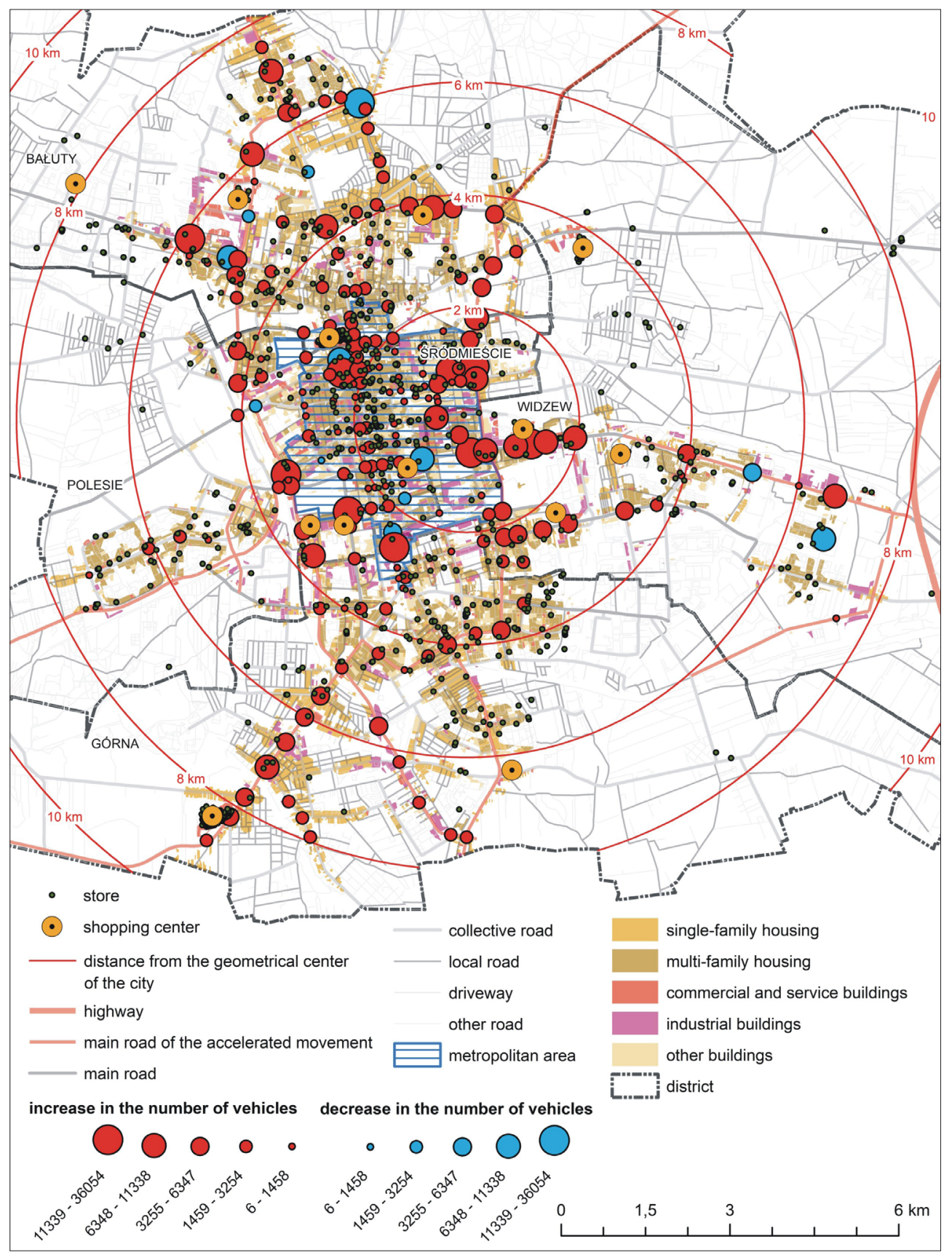

Fig. 6: Changes in the load on the road network between Saturdays before Sundays with and without the ban on trading against the background of development type (increases and decreases in relation to a trading Sunday; average 24-hour changes). Source: authors' survey

Changes in the traffic volume on the road network between trading and non-trading Sundays indicate that the actual differences for the benefit of trading Sundays are visible in the opening hours of most shopping facilities (Fig. 7). It is intriguing that the aforementioned differences are much smaller than those observed on Saturdays despite the fact that some people reschedule shopping previously done on Sunday either to weekdays or Saturdays.

One reason for this state of affairs may be the fact that despite Sunday restrictions on trade, most inhabitants did not change the frequency of their journeys, only shifting their destination from shopping centres to other forms of outdoor activities. The spatial distribution of changes in the load on the road network on Sundays may be some confirmation of the questionnaire survey results. A greater load is observed along the arteries connecting the city with its surroundings (showing outward journeys to visit family and friends). Changes are smaller on the roads within the city centre (which is a district located centrally and traditionally considered a trading area), and there are more observations indicating drops in the load in relation to trading Sundays (Fig. 8).

The research also aimed to check if the restriction on Sunday trading had a major impact on the load on the road network on weekdays. Due to the complexity of daily city mobility on a weekday and much heavier traffic in this period, however, it is not possible to show the aforementioned relations either on the basis of the comparative method used earlier or more advanced attempts to capture this phenomenon. Sunday retail restrictions contribute to an increase in car traffic both at weekends (Fig. 9) and during the week as a whole (Fig. 10). 


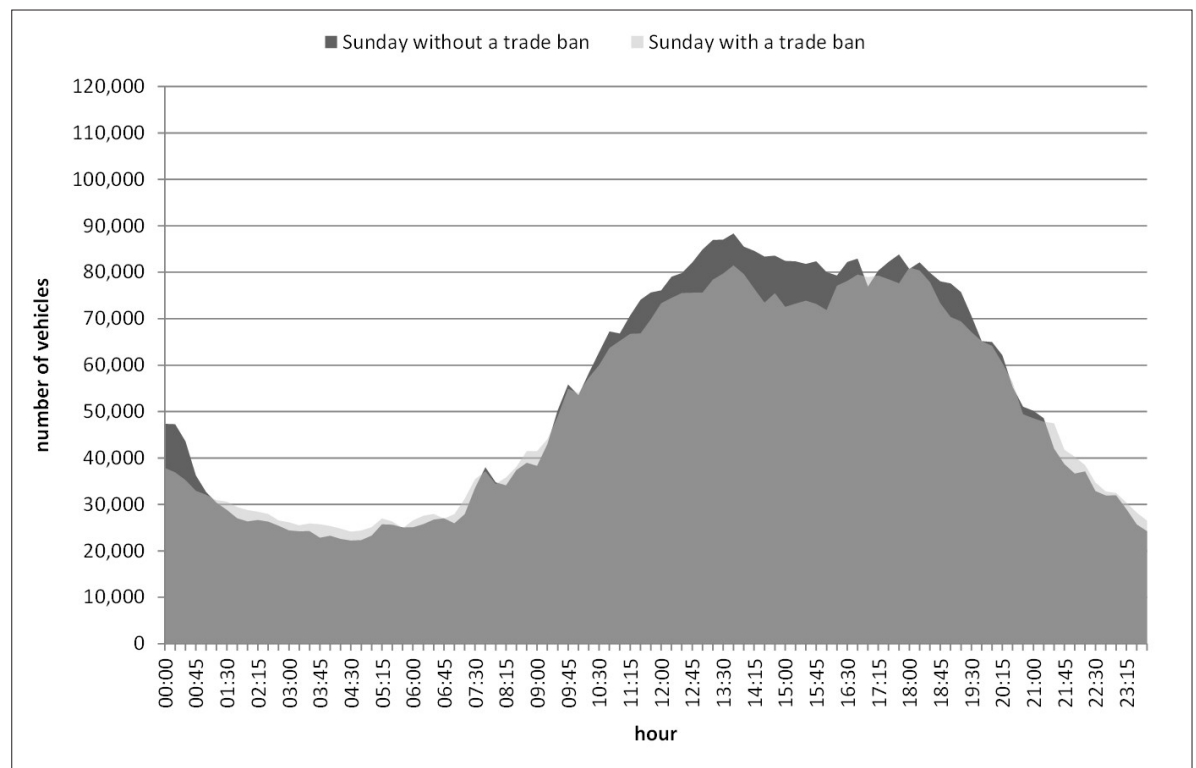

Fig. 7: The number of vehicles on Sundays with and without the ban on trading Source: authors' survey

The fact that people avoided shopping on non-working days, which refers to Sundays in particular, stems from long-held practices, habits, and social norms, according to which Sunday is a statutory holiday (Č́byová et al., 2014; Szromnik, 2017). Its traditional Christian image (Siguaw and Simpson, 1997) changed substantially during the period of socio-economic and political transformation (Čábyová et al., 2014; Szromnik and Wolanin-Jarosz, 2018), and, in consequence, people began to spend their leisure time differently (Rochmińska, 2011). Those persons professionally active-younger employees in particular - only had free time on non-working days, which limited the scope for this type of activity to weekends (de Pourbaix, 2010). As a result, there was a shift in the weekly schedule regarding various activities related to culture, education, recreation, socialising with friends and family, as well as shopping and visiting retail facilities (Bywalec, 2017).

Such a shift does not apply exclusively to Poland, as various studies have shown that people in many other countries have similar preferences (Zhong et al., 2008; Agarwal, 2004). Undoubtedly, the 2018 introduction of the Sunday retail restrictions has led to a change in the model of behaviour (Jękot, 2018; Stelina, 2018), confirmed by our research. There are, however, quite diverse opinions on the impact of said restrictions. Some believe them to have had beneficial effects - people can rest and spend more time with their families; while others (mostly young people) claim that they have been deprived of the possibility to do their weekend shopping in a relaxed and unhurried fashion (Szromnik, 2017). In September 2016, the Public Opinion Research Centre carried out a survey on a representative sample of 981 adult Polish citizens. The results showed that the majority did their shopping on Sundays (79\%) (CBOS, 2016). This was influenced by such factors as age, employment status, city size and religiousness (Adamiec and Grodzka, 2017; Szromnik, 2017). The phenomenon of Sunday shopping, which was mainly done by younger people, is also confirmed by other researchers (Williamson et al., 2006). The process of explaining the changes to the weekly shopping cycle can also be facilitated by analysis of the first and last days of the 'working week' - i.e. just after and before the weekend (Perchla-Włosik, 2010).
Not only have the implemented restrictions contributed to changes in the weekly shopping cycles (which - in the case of our research - is confirmed by the results of the survey and data from induction loops), but they have also influenced shifts in motivations, numbers, modal division, and duration of trips.

\section{Conclusions and policy implications}

The realisation of the main research objectives of this project allowed us to draw significant conclusions which are likely to supplement existing knowledge of the relations between customer behaviours and transport behaviours. The methodological approach employed takes into account questionnaire surveys and the objectivised ITS measurements, and focuses on an exceptional research area (a city which for years functioned under a socialist regime) and thus renders the results relatively unique in nature.

The main conclusion to be drawn from this study of the impact of the statutory Sunday retail restrictions on the transport behaviours of people living in the large Polish city of Lodz, is that the introduction of restrictions on retail facilities results in a considerable increase in mobility (number of trips) of residents on working days, which is not reflected by a proportionate drop on non-trading weekends (Sundays in particular). This is confirmed by analyses of citizen transport behaviours conducted on trading and nontrading Sundays, and by research on the time and spatial differentiation of their mobility, the expression of which is the load on the urban road network (including daily and hourly changes of differences in vehicle numbers on the urban road and street network).

Data from the ITS concerning volumes of road traffic measured by means of induction loops is of considerable value in research into changes in transport behaviour despite the many aforementioned difficulties. The overall results may be presented because of the analysis made on their basis connected with comparison of traffic volumes in the space of a diversified functional and spatial structure, but these results have great cognitive value when combined with research aimed at characterising transport system participants and their destinations. 


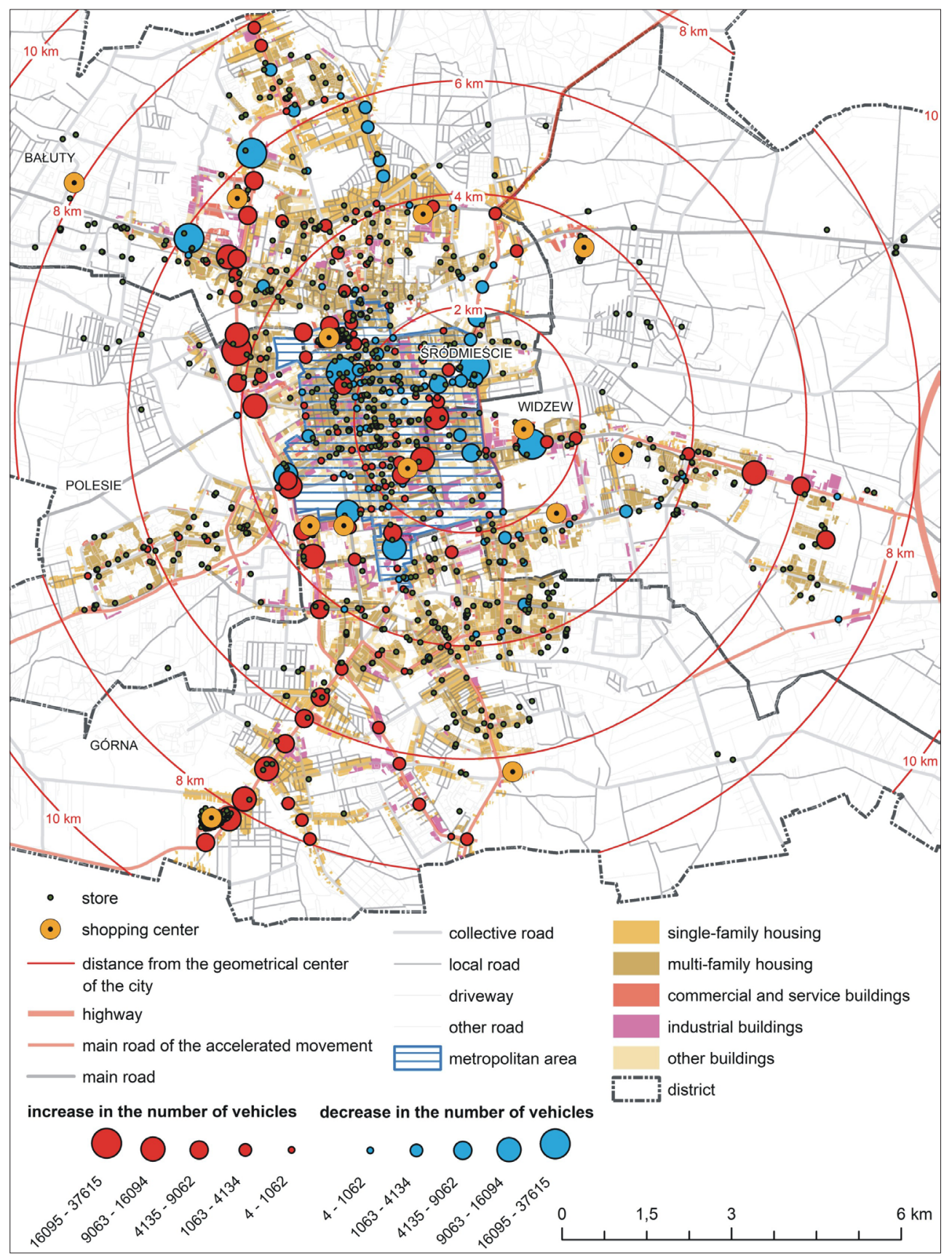

Fig. 8: Changes in the load on the road network between trading and non-trading Sundays with and without the ban on trading against the background of land cover and development type (increases and decreases in relation to trading Sunday) (average 24-hour changes). Source: authors' survey

A closer correlation between the data obtained via the survey and from the ITS would be possible if we retrieved information recorded by ITS cameras, which could recognise licence plates and 'track' vehicles within the area covered by the ITS. For such a purpose, however, we would have to obtain information on the number plate of the vehicle driven by a given respondent, which is against privacy laws. Another issue would be the fact that some urban areas are not covered by the ITS system.

The results of the first specific objective, related to the analysis of residents' transport behaviours on trading and non-trading Sundays, shows that those shopping needs which could not be fulfilled on a Sunday are now satisfied on the remaining days of the week and, consequently, mobility shifts to those days when trading is allowed. In addition, the time previously devoted to Sunday shopping is used by the inhabitants not only to stay at home but also to undertake new (not accomplished earlier) activities which required travelling. Additionally, the modal division of means of transport used for this purpose points to the more frequent use of the car (as driver) and less frequent use of the possibilities offered by non-mechanised transport.

The study of factors responsible for possible changes in residents' transport behaviours related to the introduction of Sunday trading restrictions and the degree of their correlation (independence) with the implemented ban (the second specific research objective), shows that such changes actually occurred (especially with regard to travel motivations, modal division and duration of journeys, and mobility). Another phenomenon discovered in relation to these features is a statistically significant correlation regarding trade in general, although this correlation can be described as weak. 


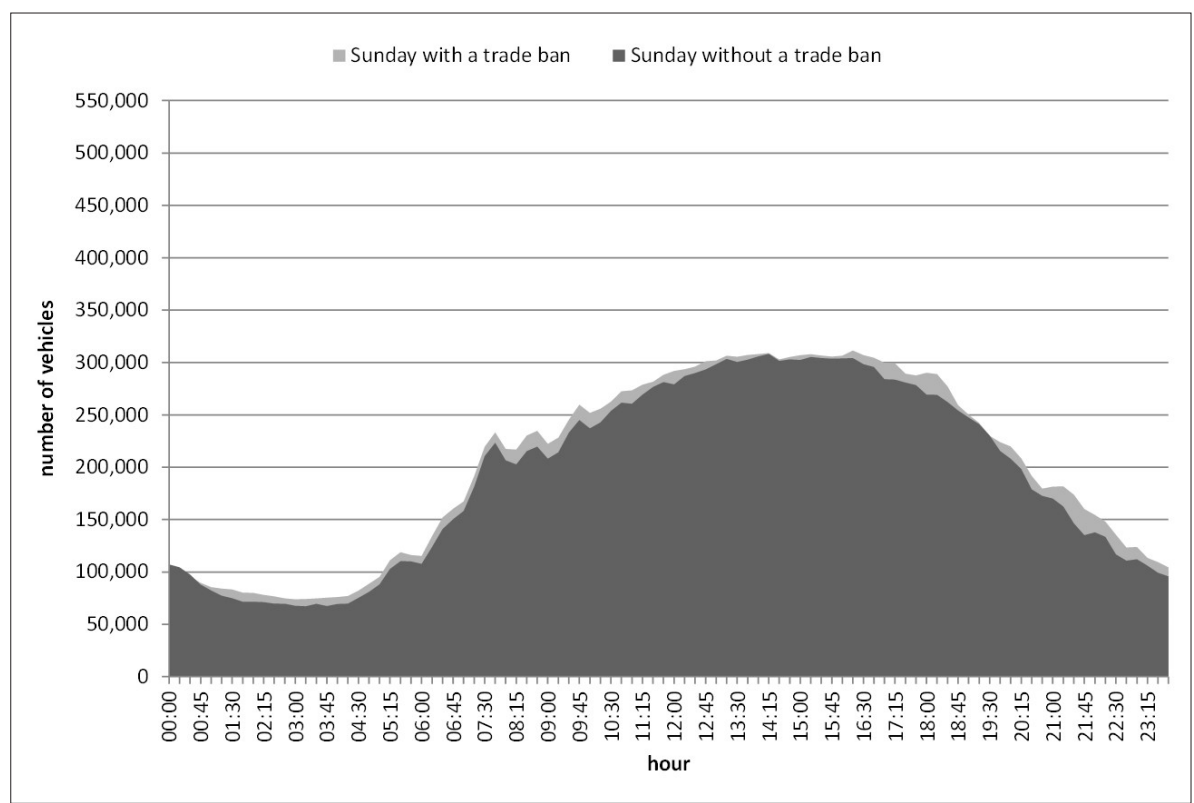

Fig. 9: The number of vehicles at the weekend with and without the trading ban Source: authors' survey

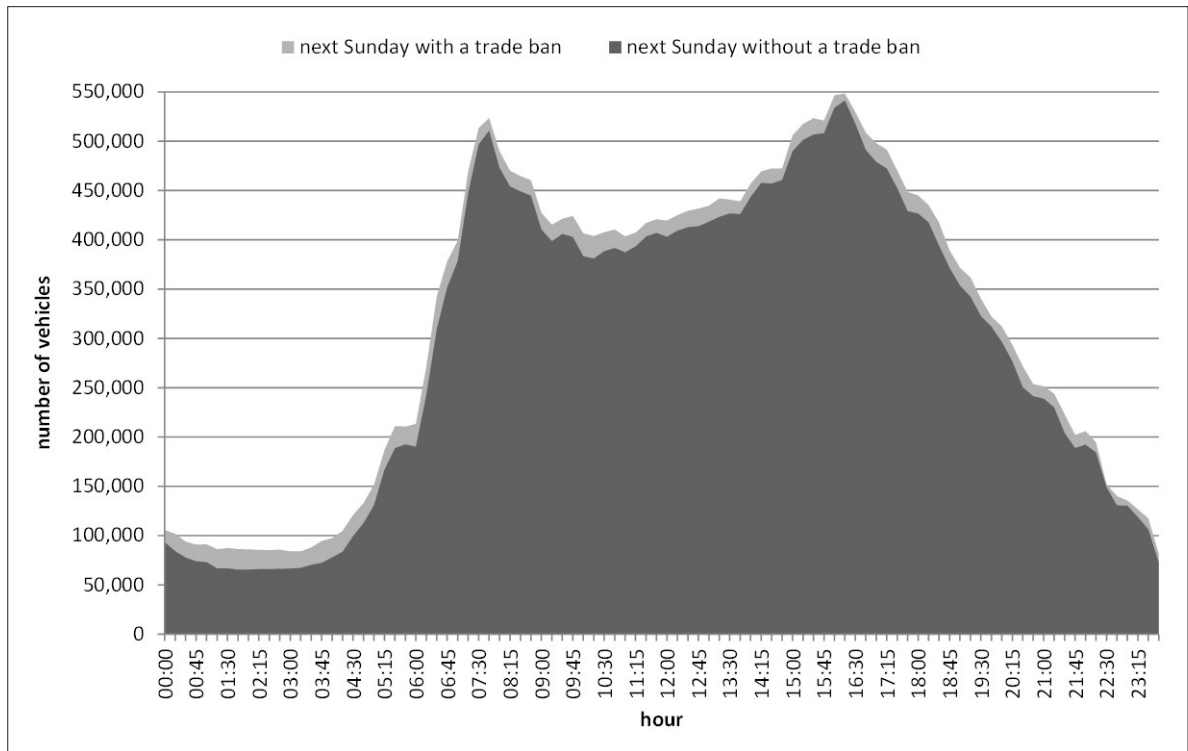

Fig. 10: The cumulated number of vehicles on Mondays, Tuesdays, Wednesdays and Thursdays before Sundays with and without the trading ban. Source: authors' survey

The analysis of the spatiotemporal features of residents' mobility, which is driven by the load of the urban road network on Sundays with and without trading restrictions (our third specific objective), indicates that changeability in the matter is clearly noticeable, and insufficiently diverse.

Changes in time are mostly distinguishable on Saturdays and Sundays (even though increased traffic flows were recorded on all days of the week with trading restrictions), and changes in space (the fourth specific research objective) mainly refer to the areas in the vicinity of shopping centres and main sections of the street and road infrastructure that serve the traffic entering and leaving the city.

Apart from the conclusions resulting from the major aims of this work, the research also established (and partly confirmed other research results in academia) that in Lodz (as a post-socialist city):

- Sunday is mainly used as a day of passive rest at home;
- Non-trading Sundays foster the undertaking of recreation and sports as well as cultural and leisure activities;

- The aforementioned activities replace Sunday shopping, while also influencing any decisions over attending church;

- Inhabitants are generally willing to travel longer distances to do non-food shopping than they are for food shopping; and

- During trading Sundays it is women rather than men who go out, and additionally women do shopping more often.

This research was conducted in the first year of the imposition of the partial ban on Sunday trading. It seems that changes in the demand for transport which took place in this period, may still need to undergo further transformations due to: firstly, achieving a better balance where the retail and transport systems meet; and secondly, owing to the gradual increased restriction on Sunday trading. 
Research into people's transport behaviours and spatial mobility is important for a number of reasons. It returns invaluable analytical materials that allow us to recognise and describe principles governing traffic and its modelling; it provides data for studying trends and any corresponding necessity for changes in the researched territories; and for preparing insightful reports, projects and evaluations of the effectiveness of individual constituents and devices of the transport system. It also facilitates analyses of traffic as a sociological phenomenon. The results can be directly translated into transport studies (which take into account spatial management, transportation schedules, mobility plans, and industrial strategies and policies), traffic models (particularly those related to the incorporation of retail facilities in urban space), the designs of roads, carparks and junctions (which are capable of taking traffic for precisely specified purposes), and strategies of traffic organisation and traffic light management (varied traffic signal timing adjusted to trading and non-trading days).

The results also facilitate the monitoring of the effectiveness of implemented transport policies, preparation of feasibility studies, economic analyses, environmental studies, and traffic safety reports, commercial applications of traffic data, design and supervision of traffic management systems, and implementation of electro-mobility (choosing locations for charging points, delineating the boundaries of zero-emission zones, etc.). This research project, based on a questionnaire survey, automated data from various types of sensors and detectors, and image analysis, applied to determine the impact of the legislation that does not refer directly to transport laws and regulations, also returns wide ranging implications for both national and local, urban transport policies, the purpose of which is to generate transport behaviours that are concordant with, for instance, the principles of sustainable mobility. The results of this study can also be utilised by lawmakers as material facilitating verification and validation of the premises behind the introduction of laws and regulations.

\section{Acknowledgements}

This article is based on the results of the research project No. 2018/02/X/HS4/00093 financed by the National Science Centre Poland, and the research project No. 2019/33/N/ HS4/01733 financed by the National Science Centre Poland.

\section{References:}

Act on Retail restrictions on Sundays and Public Holidays as well as Some Other Specified Days (Item 305 published in the Official Journal of Laws of the Republic of Poland ("Dziennik Ustaw")).

ADAMIEC, J., GRODZKA, D. (2017): Społeczne uwarunkowania handlu w niedziele. Infos, 1(224): 1-4.

AGARWAL, A. (2004): A comparison of weekend and weekday travel behavior characteristics in urban areas. MS Thesis, Department of Civil and Environmental Engineering, University of South Florida.

ÅSLUND, A. (1985): The Development of the Private Sector in Poland. In: Åslund, A. [ed.]: Private Enterprise in Eastern Europe (pp. 19-117). London, Palgrave Macmillan.

BARTOSIEWICZ, B., PIELESIAK, I. (2019): Spatial patterns of travel behaviour in Poland. Travel Behaviour and Society, 15: 113-122.
BELL, R., DAVIES, R., HOWARD, E. (1997): The changing structure of food retailing in Europe: the implications for strategy. Long range planning, 30(6): 853-861.

BENNISON, D. J., DAVIES, R. L. (1980): The impact of town centre shopping schemes in Britain: Their impact on traditional retail environments. Progress in Planning 14(3): 1-104.

BOROWSKA-STEFAŃSKA, M., KOWALSKI, M., WIŚNIEWSKI, S. (2019): Wewnętrzna samochodowa dostępność transportowa Łodzi w świetle pomiarów z Inteligentnych Systemów Transportowych. Prace Geograficzne, 159: 7-24.

BOROWSKA-STEFAŃSKA, M., WIŚNIEWSKI, S. (2019): Mobilność codzienna osób starszych w Łodzi. Łódź, Wydawnictwo Uniwersytetu Łódzkiego.

BYWALEC, C. [ed.] (2017): Gospodarstwo domowe Ekonomika, Finanse, Konsumpcja. Kraków, Wydawnictwo Uniwersytetu Ekonomicznego w Krakowie.

ČÁBYOVÁ, L., FAŠIANG, T., KOLLÁROVÁ, D., MUŽÍKOVÁ, D. (2014): Sunday christian significance and the saints days shopping behaviour. European Journal of Science and Theology, 10(1): 43-54.

CARP, F. M. (1988): Significance of mobility for the wellbeing of the elderly. Transportation in an aging society: Improving mobility and safety of older persons, 2: 1-20.

CBOS (2016): Komunikat z badań, Zakaz handlu w niedzielę, Warszawa.

CHOI, Y. J., JEONG, J. (2016): Effects of the Sunday shopping restriction in Korea. Contemporary Economic Policy, 34(1): 203-215.

CHUDZYŃSKA, I. [ed.] (1985): Struktura przestrzenna handlu detalicznego w Warszawie. Wrocław, Zakład Narodowy im. Ossolińskich.

CUDNY, W. (2016): Manufaktura in Łódź, Poland: An example of a festival marketplace. Norsk Geografisk Tidsskrift, 70(5): 276-291.

DE POURBAIX, P. (2010): Proces zakupowy młodych nabywców.Zeszyty Naukowe Uniwersytetu Szczecińskiego Ekonomiczne Problemy Usług, 54: 263-270.

DIJKGRAAF, E., GRADUS, R. (2006): Deregulating Sunday Shop Policies. Tinbergen Institute Discussion Paper, 06003/3, Tinbergen Institute, Amsterdam and Rotterdam [online]. [cit. 24.10.2019]. Available at: http://hdl.handle. net/10419/86473

DIJKGRAAF, E., GRADUS, R. (2007): Explaining Sunday shop policies. De Economist, 155(2): 207-219.

DINIC-BRANKOVIC, M., DJEKIC, J., MITKOVIC, M., MITKOVIC, P., MARKOVIC-BRANKOVIC, J. (2018): Postsocialist Restructuring of City Subcenters and the Role of Shopping Centers in Nis Serbia. Journal of Urban Planning and Development, 144(2): 4018009.

DZIECIUCHOWICZ，J. (2013). Handel w przestrzeni wielkomiejskiej. Przykład Łodzi, Łódź. Łódź University Press.

GENAKOS, C., DANCHEV, S. (2015): Evaluating the Impact of Sunday Trading Deregulation. CEP Discussion Paper, 1336: $1-22$.

GRADUS, R. (1996): The economic effects of extending shop opening hours. Journal of Economics, 64(3): 247-263. 
HANNAM, K., SHELLER, M., URRY, J. (2006): Editorial: Mobilities, immobilities and moorings. Mobilities, 1(1): 1-22.

HEFFNER, K., TWARDZIK, M. (2015): The impact of shopping centers in rural areas and small towns in the outer metropolitan zone (the example of the Silesian Voivodeship). European Countryside, 7(2): 87-100.

HOPKINS, J. S. P. (1991): West Edmonton Mall as a centre for social interaction. The Canadian Geographer, 35(3): 268-279.

HUMPHREY, C., SKVIRSKAJA, V. (2009): Trading places: Post-socialist container markets and the city. Focaal, 55: $61-73$.

JĘKOT, A. (2018): Ograniczenie i zakaz handlu w niedziele w opinii konsumentów. Zeszyty Naukowe Wyższej Szkoły Ekonomiczno-Społecznej w Ostrołęce, 30: 9-22.

KACZMAREK, T. (2011): Handel detaliczny w rozwoju funkcjonalnym i przestrzennym miast w Polsce. Rozwój Regionalny i Polityka Regionalna, 15: 67-83.

KALIŃSKI, J. (1968): Handel wewnętrzny w Polsce w latach 1944-1946. Przegląd Historyczny (1): 67-91.

KALIŃSKI, J. (2015): Etatyzacja gospodarki w okresie rządów komunistycznych w Polsce. Kwartalnik Kolegium Ekonomiczno-Społecznego Studia i Prace, 24(4): 177-201.

KAUFMANN V. (2005): Re-Thinking mobility, Ashgate, Aldershot.

KAY, J. A., MORRIS, C. N. (1987): The economic efficiency of Sunday trading restrictions. The Journal of Industrial Economics, 36(2): 113-129.

KOMORNICKI, T. [ed.] (2003): Przestrzenne zróżnicowanie międzynarodowych powiązań społeczno-gospodarczych w Polsce. Prace Geograficzne Nr. 190. Warszawa, IGiPZ PAN.

KOMORNICKI, T. (2011): Przemiany mobilności codziennej Polaków na tle rozwoju motoryzacji. Prace Geograficne Nr. 227. Warszawa, IGiPZ PAN.

KOWALSKI M., WIŚNIEWSKI, S. (2017b): Natężenie ruchu a zagospodarowanie Łodzi - zarys problematyki w świetle danych z Obszarowego Systemu Sterowania Ruchem. Prace Komisji Geografii Komunikacji PTG, 20(4): 20-36.

KOWALSKI, M. (2018): Торгові центри в просторі польських міст. Містобудування та територіальне планування, 66: 265-286.

KOWALSKI, M., WIŚNIEWSKI, S. (2017a): Centrum handlowe jako czynnik ruchotwórczy w transporcie samochodowym - przykład Portu Łódź. Przegląd Geograficzny, 89(4): 617-639.

KRAFT, S. (2014): Daily spatial mobility and transport behaviour in the Czech Republic: Pilot study in the Písek and Bytřice and Pernštejnem regions. Human Geographies: Journal of Studies and Research in Human Geography, 8(2): 51-67.

LAMPRECHT, M., WOJNAROWSKA, A. (2013): The structure of urban space in Łódź. In: Habrel, M. Wojnarowska, A. [eds.]: Lviv and Łódź at the turn of $20^{\text {th }}$ century. Spatial development and functional structure of urban space (pp. 165-191). Łódź, Łódź University Press.

LESIAKOWSKI, K. (2012): Zaopatrzenie mieszkańców Łodzi w artykuły codziennego użytku w latach 1980-1983. Przegląd Nauk Historycznych, 11(1): 101-128.
LI, J., VAN ZUYLEN, H. J., WEI, G. (2014): Loop detector data error diagnosing and interpolating with probe vehicle data. Paper presented at $93^{\text {rd }}$ Annual Meeting Transportation Research Board, Washington 1216.01.2014 [online]. [cit. 24.10.2019]. Available at: http://resolver.tudelft.nl/uuid:02bc7359-7136-4844-8691f95436e $7340 \mathrm{c}$

LIJEWSKI, T. (1998): Rozmieszczenie ruchu drogowego w Polsce. Prace Komisji Geografii Komunikacji PTG, 4: 57-66.

LOWE, M. (2005): The regional shopping centre in the inner city: a study of retail-led urban regeneration. Urban Studies, 42(3): 449-470.

MAJCHRZAK, K. (2007): Centrum handlowe jako atrakcja turystyczna ery postturystyki na przykładzie Starego Browaru w Poznaniu. Ekonomiczne Problemy Turystyki, 9: $181-184$

MARCIŃCZAK， S. (2007): The socio-spatial structure of postsocialist Łódź, Poland. Results of national census 2002. Bulletin of Geography. Socio-economic Series, 8: 65-82.

MENES, E. (2001): Społeczno - ekonomiczne aspekty rozwoju motoryzacji indywidualnej w Polsce. Przegląd Komunikacyjny, 1: 1-6.

MILEWSKA-OSIECKA, K. [ed.] (2010): Budownictwo mieszkaniowe aglomeracji łódzkiej (zróżnicowanie I struktura przestrzenna po roku 1994). Łódź, Wydawnictwo Uniwersytetu Łódzkiego.

MORRISON, S. A., NEWMAN, R. J. (1983): Hours of Operation Restrictions and Competition among Retail Firms. Economic Inquiry, 21: 107-114.

NOOTEBOOM, B. (1983): Trading Hours and Economy of Scale in Retailing. European Small Business Review, 1: $57-62$.

NOVÁK, J., SÝKORA, L. (2007): A city in motion: time-space activity and mobility patterns of suburban inhabitants and the structuration of the spatial organization of the Prague metropolitan area. Geografiska Annaler: Series B Human Geography, 89(2): 147-168.

PAUL, A. (2015): After work shopping? Employment effects of a deregulation of shop opening hours in the German retail sector. European Economic Review, 80: 329-353.

PERCHLA-WŁOSIK, A. (2010): Czas wolny jako wyraz zachowań konsumenckich młodych Polaków Ujęcie socjokulturowe. Zeszyty Naukowe Uniwersytetu Szczecińskiego Ekonomiczne Problemy Usług, 54: 113-122.

REMBOWSKA, K. (2008): Kulturowy aspekt przemian rynku usług. Space - Society - Economy, 8: 5-15.

RITZER, G. (2005): Enchanting a disenchanted world: revolutionizing the means of consumption. Thousand Oaks, London, New Delhi, Pine Forge Press.

ROCHMINSSKA, A. (2011): Centra handlowe - miejsca spędzania czasu wolnego przez łodzian. Acta Universitatis Lodziensis Folia Geographica Socio-Oeconomica, 11: $1-12$.

ROCHMIŃSKA, A. (2016): Shopping centres as the subject of polish geographical research. Geographia Polonica 89(4): 521-535. 
ROMANOWSKA, A., JAMROZ, K. (2015) Wielkopowierzchniowe obiekty handlowe: zwykłe generatory ruchu czy źródła problemów transportowych?. Transport miejski i regionalny, 2: 4-13.

SIGUAW, J. A., SIMPSON, P. M. (1997): Effects of religiousness on Sunday shopping and outshopping behaviours: a study of shopper attitudes and behaviours in the American South. The International Review of Retail, Distribution and Consumer Research, 7(1): 23-40.

STELINA, J. (2018): Legal restrictions on work on Sundays and festive days in Poland. Istorie, Cultura, Cetatenie in Uniunea Europeana, 11(1): 105-114.

SZROMNIK, A. (2017): Handel i zakupy w niedzielę w opinii społecznej - studium porównawcze (cz. I). Handel Wewnętrzny, 368(3/2): 409-422.

SZROMNIK, A., WOLANIN-JAROSZ, E. (2018): Social acceptance of retailing on Sunday in Poland - results of surveys. In: Mihalčová, B. et al. [eds.]: Production Management and Business Development (pp. 221-226). London, Taylor \& Francis.

SZUL, E. (2015): Obrazowanie współczesnego konsumenta ujęcie socjologiczne. Nierówności Społeczne a Wzrost Gospodarczy, 42: 20-31
TAYLOR, Z. (2000): Przekształcenia sieci handlu detalicznego i gastronomii w okresie transformacji społecznogospodarczej Polski, Wrocław, Wydawnictwo Continuo.

TEMPERINI, V., GREGORI, G. L. (2015): The impact of the liberalisation of opening hours on small retail enterprises. International Journal of Sales, Retailing \& Marketing, 4(5): 47-59.

VILHELMSON, B. (1999): Daily mobility and the use of time for different activities. The case of Sweden. GeoJournal, 48(3): 177-185.

WILLIAMSON, B., HARGREAVES, J., BOND, J., LAY, H. (2006): The economic costs and benefits of easing Sunday shopping restrictions on large stores in England and Wales. A report for the Department of Trade and Industry [online]. [cit. 24.10.2019]. Available at: www. gov.uk

XAVIER, M. (2018): Dreaming in the temples of consumption: shopping malls and department stores dreams. In: Xavier, M. [eds.]: Subjectivity, the Unconscious and Consumerism (pp. 289-319). Cham, Palgrave Macmillan.

ZHONG, M., HUNT, J. D., LU, X. (2008): Studying differences of household weekday and weekend activities: a duration perspective. Transportation Research Record, 2054: 28-36.

\section{Please cite this article as:}

BOROWSKA-STEFAŃSKA, M., KOWALSKI, M., WIŚNIEWSKI, S. (2020): Changes in urban transport behaviours and spatial mobility resulting from the introduction of statutory Sunday retail restrictions: A case study of Lodz, Poland. Moravian Geographical Reports, 28(1): 29-47. Doi: https://doi.org/10.2478/mgr-2020-0003 